\title{
ASSESSMENT OF NUTRITIONAL RISK IN CANCER PATIENTS TREATED WITH SYSTEMIC ANTINEOPLASTIC TREATMENT
}

\author{
PETRA LEPETIĆ ${ }^{1}$, ANA TEČIĆ VUGER ${ }^{1}$, MIRJANA PAVLOVIĆ ${ }^{1}$, \\ LJUBICA VAZDAR ${ }^{1}$, MARTINA ŠEPETAVC ${ }^{2}$ and ROBERT ŠEPAROVIĆ ${ }^{1}$ \\ ${ }^{1}$ Department of Medical Oncology, Division for Radiotherapy and Medical Oncology, \\ University Hospital for Tumors Zagreb, Sestre milosrdnice University Hospital Center, Zagreb, Croatia; \\ ${ }^{2}$ Farmacia, Community Pharmacies Chain, Zagreb, Croatia
}

\begin{abstract}
Summary
This study aims to explore if there is a change in nutritional risk and body mass index (BMI) in cancer patients during the systemic antineoplastic treatment. We retrospectively analyzed data collected from 216 cancer patients treated at the Department of Medical Oncology, University Hospital for tumors, Sestre Milosrdnice University Hospital Center, Zagreb, Croatia, with systemic antineoplastic therapy in the period from 05/2016 to 05/2018. In our study, we included both patients treated with systemic therapy for the first time and patients treated repeatedly (only patients who have had at least six months free period after the last treatment course were eligible). We included male and female patients with breast cancer, colorectal cancer, pancreatic cancer, and head and neck cancer. Around 75\% of patients had metastatic disease. We analyzed data collected from Nutritional Risk Score-2002 (NRS-2002) screening and results of BMI, at first hospitalization, and after three months of systemic antineoplastic treatment. All patients at high nutritional risk (NRS 3-4) received the nutritional intervention, which included enteral nutritional supplement and education of patient and patient's family about nutrition in oncological patients. We used the Wilcoxon test for the NRS score and t-test for a depended variable for BMI data. The initial average BMI of all patients was $26,45 \mathrm{~kg} / \mathrm{m}^{2}$. Of all screened patients, around $78 \%$ of them were at mild nutritional risk (NRS 1-2), while around $22 \%$ of them were at high nutritional risk (NRS 3-4). We recorded a statistically significant decrease both in NRS of the entire screened population of patients after three months of systemic antineoplastic treatment and after specific nutritional intervention in high-risk patients (most patients were at mild nutritional risk, while less than $8 \%$ of them were at high nutritional risk). There was no significant change in BMI in the observed period (average BMI was 26, 59 kg/ $\mathrm{m}^{2}$ ). It seems, systemic antineoplastic treatment, along with early nutritional intervention with enteral nutritive supplementation and education, can significantly contribute to the decrease of the nutritional risk.
\end{abstract}

KEYWORDS: nutritional risk (NR), body mass index (BMI), systemic antineoplastic treatment

\section{Sažetak}

PROCJENA NUTRITIVNOG RIZIKA BOLESNIKA TIJEKOM SUSTAVNOG ANTINEOPLASTIČNOG LIJEČENJA

Cilj ovog rada je procijeniti promjena u nutritivnom riziku i indeksu tjelesne mase (ITM) onkoloških bolesnika tijekom sustavnog antineoplastičnog liječenja. Retrospektivno su analizirani podatci 216 bolesnika koji su od 05/2016 do 05/2018 liječeni na Odjelu internističke onkologije Klinike za tumore, KBC Sestre milosrdnice, Zagreb, Hrvatska. Obuhvaćeni su bolesnici po prvi put liječeni sustavnom antineoplastičnom terapijom i/ili koji u prethodnih 6 mjeseci nisu bili liječeni niti jednim vidom onkološkog liječenja. Zastupljeni su bolesnici obaju spolova, oboljeli od raka dojke, debelog i završnog crijeva, gušterače te glave i vrata. Oko 75\% bolesnika imalo je metastatsku bolest. Korišteni su rezultati NRS 2002 nutritivnog probira te rezultati indirektne procjene sastava tijela izračunom indeksa tjelesne mase (ITM) prilikom prve hospitalizacije te 
nakon 3 mjeseca sustavnog antineoplastičnog liječenja. U svih bolesnika koji su bili u visokom nutritivnom riziku (NRS 3-4) je provedena nutritivna intervencija uvođenjem enteralne prehrane te edukacije bolesnika i obitelji o prehrani onkoloških bolesnika. Za statistički izračun su korišteni Wilcoxonov test za podatke o NRS-u te t-test za zavisne uzorke za podatke o ITM-u. Inicijalni prosječni ITM je na početku liječenja bio $26,45 \mathrm{~kg} / \mathrm{m}^{2}$. Inicijalnim nutritivnim probirom je utvrđen blagi nutritivni rizik (NRS 1-2) u oko $78 \%$ bolesnika, a oko $22 \%$ bolesnika je bilo u visokom nutritivnom riziku (NRS 3-4). Nakon 3 mjeseca specifičnog onkološkog liječenja te provođenja nutritivne potpore $u$ visoko ugroženih bolesnika, zabilježen je statistički značajan pad u nutritivnom riziku u ukupnoj ispitivanoj populaciji (većina bolesnika je bila u blagom nutritivnom riziku, dok je manje od $8 \%$ bolesnika bilo visokog nutritivnog rizika). U periodu praćenja nije bila zabilježena značajnija promjena u indeksu tjelesne mase (prosječni ITM je bio $26,59 \mathrm{~kg} / \mathrm{m}^{2}$ ). Sustavno antineoplastično liječenje uz ranu nutritivnu intervenciju i edukaciju doprinosi smanjenju znakova bolesti i poboljšanju općeg stanja bolesnika te može značajno smanjiti nutritivni rizik.

KLJUČNE RIJEČI: nutritioni rizik (NR), indeks tjelesne mase (ITM), sustavno antineoplastično liječenje

\section{INTRODUCTION}

Weight loss, nutritional risk, and malnutrition are frequent problems in cancer patients and is often the presenting sign of malignant disease. The physiological abnormalities due to the tumor (malabsorption, obstruction, diarrhea, vomiting), the host response to the tumor (causing anorexia and altered metabolism), and the side-effects of anticancer treatment can al cause weight reduction $(1,2)$. Older publications reported that the frequency of weight loss and malnutrition in cancer patients ranges from $31-87 \%$, depending on the tumor site and stage (3). This data is consistent with newer publications in which nutrition risk prevalence ranges from $25 \%$ to over $70 \%$ based on nutritional assessment (4). According to the World Health Organization, in 2016. 39\% of adults were overweight - $39 \%$ of men and $40 \%$ of women (5). Therefore it became challenging to identify malnutrition in the overweight population and, consequently, those in needing nutritional intervention. Although unintentional weight loss is one of the first signs of malignancy, obese patients underestimate the importance of that sign and usually do not report it to their physicians. Davidson et al. reported in their study 23 malnourished patients with normal or increased body mass index (BMI), which suggests that BMI and self-reporting of symptoms are not reliable measures for identifying all patients at risk of malnutrition or with poor nutritional status (6).

Specific oncological treatment and cancer itself, cause metabolic and physiological alterations that affect the nutritional status of patients (7). Patients usually report chemotherapy-induced nausea and vomiting, dysgeusia, diarrhea, or consti- pation as a common side - effects of systemic anticancer treatment, which also has an impact of deficient alimentation and malnutrition. Adverse outcomes such as increased morbidity, poor prognosis, intolerance of treatment, and a decrease in quality of life can all be exacerbated by malnutrition. This study aims to explore the change in nutritional risk and body mass index (BMI) in cancer patients during the systemic antineoplastic treatment.

\section{MATERIAL AND METHODS}

We retrospectively analyzed data collected from 216 cancer patients who were treated at the Department of Medical Oncology with systemic antineoplastic therapy in the period from 05/2016 to $05 / 2018$. In our study, we included both patients treated with systemic therapy for the first time and patients treated repeatedly (only patients who have had at least six months free period after the last treatment course were eligible). We included male and female patients with breast cancer, colorectal cancer, pancreatic cancer, and head and neck cancer. For nutritional assessment, we used the validated NRS-2002 screening tool on the first day of each hospitalization. It consists of an initial assessment that analyzed body mass index (BMI), history of weight loss in the last three months, changes in food intake, and severity of the underlying disease. We continue the assessment if there are one or more affirmative answers with final screening that analyzes the nutritional status and severity of disease (8). BMI was calculated as measured weight in kilograms and height in meters on the first day of hospitalization $(\mathrm{BMI}=\mathrm{kg} / \mathrm{m} \mathrm{2}$ ). We 
Table 1.

CHARACTERISTICS OF CANCER PATIENTS IN STUDIED $N=216$

\begin{tabular}{|l|l|l|l|}
\hline \multicolumn{2}{|c|}{} & $\mathrm{N}$ & $\%$ \\
\hline \multirow{4}{*}{ Gender } & Male & 97 & $44,9 \%$ \\
\cline { 2 - 4 } & Female & 119 & $55,1 \%$ \\
\hline \multirow{4}{*}{ Metastatic disease } & BC & 62 & $28,7 \%$ \\
\cline { 2 - 4 } & CRC & 139 & $64,4 \%$ \\
\cline { 2 - 4 } & HNC & 12 & $5,6 \%$ \\
\cline { 2 - 4 } & PC & 3 & $1,4 \%$ \\
\hline \multirow{4}{*}{$\begin{array}{l}\text { Age (years) } \\
\text { Number of applied cycles } \\
\text { of systemic antineoplastic } \\
\text { treatment in observed } \\
\text { period }\end{array}$} & No & 55 & $25,5 \%$ \\
\cline { 2 - 4 } & Yes & 161 & $74,5 \%$ \\
\cline { 2 - 4 } & Mean & 61,48 & \\
\cline { 2 - 4 } & Mean & 31 & \\
\cline { 2 - 4 } & Minimum & 2 & \\
\cline { 2 - 4 } & Maximum & 8 \\
\hline
\end{tabular}

Abbreviations: BC - breast cancer; CRC - colorectal cancer; HNC - head and neck cancer; PC - pancreatic cancer calculated the BMI on the first day of each subsequent hospitalization. According to BMI, patients were categorized as underweight $(\mathrm{BMI}<18,5)$, normal weight (BMI 18,5- 24,9), overweight (BMI 25$29,9)$ and obese (BMI >30) (9). We analyzed data collected from NRS-2002 screening and results of BMI, at first hospitalization, and after three months of systemic antineoplastic treatment. All patients at high nutritional risk (NRS 3-4) received the nutritional intervention, which included enteral nutritional supplement and education of patient and patient's family about nutrition.

Statistical analysis was based on the Wilcoxon test for the NRS score and Student's t-test for a depended variable for BMI data.

\section{RESULTS}

The majority of our 216 patients in the study, $74.5 \%$ of them, were in the metastatic stage of the disease. Most of the patients had colorectal cancer

Table 2.

DESCRIPTIVE STATISTICS OF ANALYSED BMI AND NRS

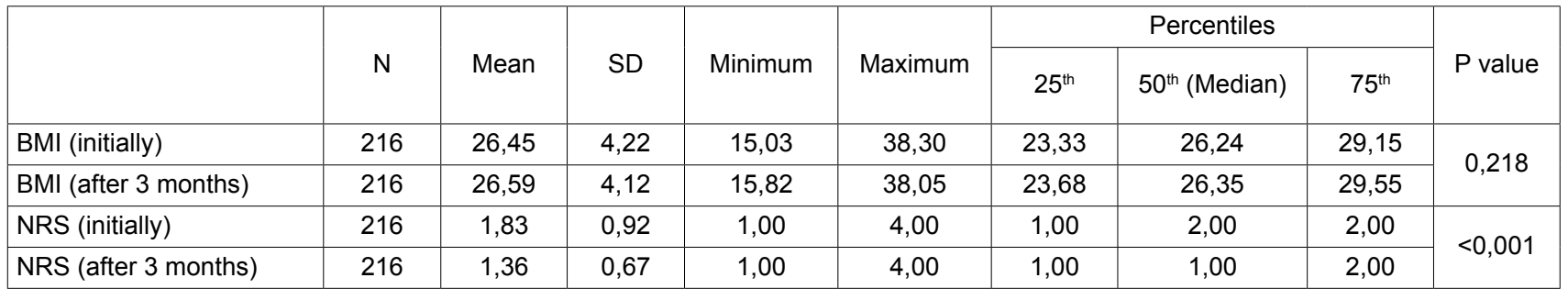

Abbreviations: BMI- body mass index; NRS: nutritional risk score

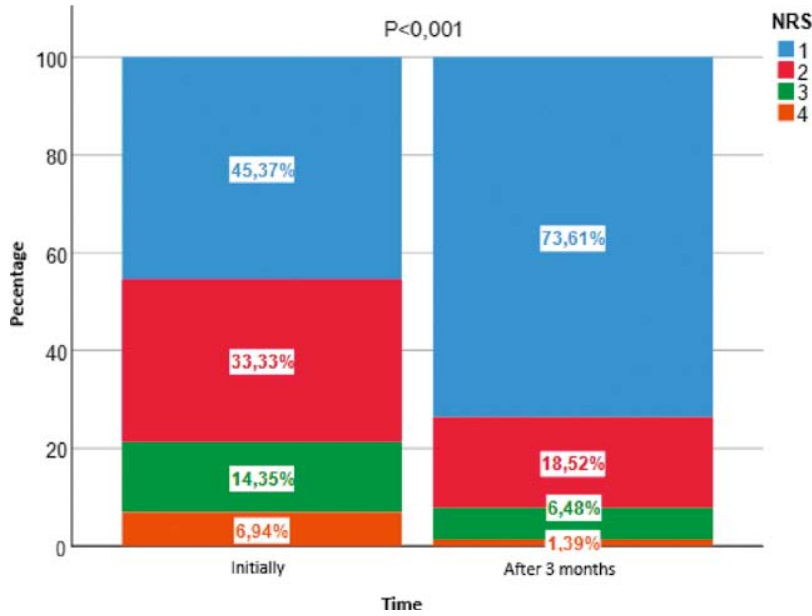

Figure 1. Statistically significant decrease in nutritional risk score during an observed period (around 63\%), followed by breast cancer (approximately $28 \%$ ). The initial average BMI of all patients was $26.45 \mathrm{~kg} / \mathrm{m}^{2}$. Of all screened patients, around $78 \%$ were at mild nutritional risk (NRS $1-2$ ), while about $22 \%$ of them were at high nutritional risk (NRS 3-4) at the beginning of systemic antineoplastic treatment. Table 1 shows the general characteristics of the studied sample. We recorded a statistically significant decrease in NRS of the entire screened population of patients after three months of systemic antineoplastic treatment and after specific nutritional intervention in highrisk patients (most patients were at mild nutritional risk, while less than $8 \%$ of them were at high nutritional risk) (Figure 1). There was no significant change in BMI in the observed period (average BMI was $26.59 \mathrm{~kg} / \mathrm{m}^{2}$ ) (Table 2). 


\section{DISCUSSION}

Our study showed that nutritional risk is still highly prevalent in oncological patients despite the multidisciplinary oncological treatments. The nutritional risk in the metastatic disease correlates with the burden of the disease and the number of comorbidities (10). Hebutern and al. stressed the importance of nutritional treatment in the overall treatment strategy (11). The general population is overweight, which is consistent with mean BMI in our study, and three month period is too short to follow up with a significant change in BMI. Our results of a decrease in NRS during systemic treatment in three months period due to nutritional intervention is consistent with one recent study of Matelaro and al. (12). They also pointed out the importance of awareness of potential nutritional risk in cancer patients and value that dietary/nutritional measures from the start of treatment aim to improve the nutritional status or even prevent its deterioration. Early nutritional intervention with enteral nutritive supplementation and education of patients and their families about dietary needs and the importance of nutritional support significantly contribute to decreasing the nutritional risk.

\section{CONCLUSION}

Nutritional assessment and early nutritional intervention should be incorporated into the therapy plan for each cancer patient from the beginning since it improves cancer therapy tolerance and the quality of life. Existing nutritional assessment tools recognize patients at nutritional risk. The importance of continuous nutritional interventions throughout the care of oncology patients needs to be recognized by all concerned with malignant disease management.

\section{REFERENCES}

1. Capra S, Ferguson M, Ried K. Cancer: impact of nutrition intervention outcome - nutrition issues for patients. Nutrition. 2001;17:769-72.

2. Martin C. Calorie, protein, fluid and micronutrient requirements. In: McCallum P, Polisena C, eds. The clin- ical guide to oncology nutrition. Chicago: The American Dietetic Association, 2000:40-60.

3. Dewys WD, Begg C, Lavin PT, Band Pr, Bennett JR, Bertino JR et al. Prognostic effect of weight loss prior to chemotherapy in cancer patients. Eastern Cooperative Oncology Group. Am J Med. 1980;69:491-97.

4. Muscaritoli M, Simone L, Farcomeni A, Larusso V, Saracino V, Barone $\mathrm{C}$ et al. Prevalence of malnutrition in patients at first medical oncology visit: the PreMiO study. Oncotarget. 2017;8:79884-96.

5. Whoint. Whoint. [Online]. [Accessed on 1 September 2019]. Available from: https://www.who.int/newsroom/fact-sheets/detail/obesity-and-overweight

6. Davidson W, Teleni L, Muller J, Ferguson M, McCarthy AL, Vick J et al. Malnutrition and chemotherapyinduced nausea and vomiting: Implications for practice. Oncology Nursing Forum. 2012;39(4):E340-5.

7. Vandebroek A.J.V, Schrijvers D. Nutritional issues in anti-cancer treatment. Annals of Oncology. 2008;19(5): v52-5.

8. Kondrup J, Rasmussen H.H, Hamberg O, Stanga Z; Ad Hock ESPEN Working Group. Nutritional risk screening (NRS 2002): a new method based on an analysis of controlled clinical trials. Clin Nut. 2003;22(3): 321-36.

9. Whois. Whoint. [Online]. [Accessed 1 September 2019]. Available from: http://www.euro.who.int/en/ health-topics/disease-prevention/nutrition/a-healthylifestyle/body-mass-index-bmi

10. Fox KM, Brooks JM, Gandra SR, Markus R, Chiou CF.Estimation of cachexia among cancer patients based on four definitions. J Oncol. 2009;2009:693458. doi: 10.1155/2009/693458. Epub 2009 Jul 1.

11. Hebuterne $X$, Lemarie E, Michallet M, de Montreui CB, Schneider SM, Goldwasser F. Prevalence of malnutrition and current use of nutrition support in patients with cancer. JPEN J Parenter Enteral Nutr. 2013; 38(2):196-204.

12. Mastelaro I, Pietrobom Pupin M, de Figueiredo Ribeiro SM, de Oliveira HF, Peria FM, de Carvalho da Cunha SF. Longitudinal assessment of nutritional risk in patients under chemo or radiotherapy. Rev Assoc Med Bras. 2016;62(7):659-63.

Corresponding author: Petra Lepetić, Department of Medical Oncology, Division of Radiotherapy and Medical Oncology, University Hospital for Tumors Zagreb, Sestre milosrdnice University Hospital Center, Ilica 197, Zagreb, Croatia.e-mail: petra.lepetic@gmail.com 